Journal of Animal and Feed Sciences, 12, 2003, 383-401

\title{
Acid-insoluble ash as a marker in digestibility studies: a review
}

\section{J. Sales ${ }^{1}$ and G.P.J. Janssens}

\author{
Laboratory of Animal Nutrition, \\ Department of Animal Nutrition, Genetics, Breeding and Ethology, \\ Faculty of Veterinary Medicine, Ghent University \\ Heidestraat 19, B-9820, Merelbeke, Belgium
}

(Received 23 January 2003; revised version 11 April 2003; accepted 15 July 2003)

\begin{abstract}
The use of markers to determine digestibility of feeds overcomes the need to make exact measurements of feed intake and total faecal output in the traditional total collection method. Although several external and internal markers have been evaluated through the years, a marker that satisfies all the criteria of an ideal marker is yet to be found. This review describes the use of acid-insoluble ash (AIA) as a marker in digestibility studies. Three variations of the original gravimetrically method, based on burning of organic matter in the sample by ashing, boiling in hydrochloric acid, and re-ashing, are commonly used to determine AIA contents. A summary of the recovery rate of AIA determined in several species with different diets presented a mean around $100 \%$. Of 45 studies where the AIA method was compared to the total collection method to determine digestibility of feeds in different species, 26 showed similar results, 9 an underestimation by the AIA method, and 10 an overestimation. No significant diurnal or daily variation in faecal AIA has been found in poultry, sheep, pigs, or cattle. Analytical error could be described as the most common reason for failure when using AIA as marker, especially in feeds with low natural AIA content. It is concluded that AIA presents a reliable marker with several advantages that could be successfully utilize to determine faecal digestibility in animal species under certain circumstances, and with the application of some precautions.
\end{abstract}

KEY WORDS: acid-insoluble ash, markers, digestibility, review

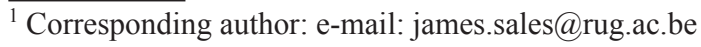




\section{INTRODUCTION}

Reliable data on nutrient availability is required to determine nutrient requirements of animals, evaluate nutritive value of feed ingredients that present potential for dietary inclusion, develop least-cost feed formulations, and to minimize environmental impact of animal production (Vandenberg and Noüe, 2001). Measurement of total feed intake and faecal output is the widely used method to determine digestibility of feeds in animal species, but the reliability of the total collection method is debatable.Animals have to be housed in metabolism cages under unnatural conditions, that may not only influence their metabolism, but could also be difficult to justify from an animal welfare perspective. Furthermore, animals will be of a specific productive status, and, in practice accurate measurement of feed intake and precise collection of all faeces are not an easy and simple task. In poultry, where cages and trays placed under cages are the most common practice for total collection, problems, such as adherence of droppings to the birds' plumage, contamination of excreta with scurf and feathers, changes in chemical composition of excreta due to microbial activity, excreta losses during removal and transfer from trays to containers, birds excreting away from the tray, and droppings being contaminated with regurgitated feed, could complicate total collection of excreta. It is difficult to detect the above and even when observed, it is almost impossible to compensate for them in a meaningful way ( $\mathrm{McNab}, 2000)$. The magnitude of these problems will increase enormously if large enclosures, due to welfare considerations, have to be used.

Certainly the use of markers to determine digestibility, as reviewed by Kotb and Luckey (1972) and Marais (2000), where measurement of feed intake and faecal output are eliminated, will be advantageous. Several external markers, such as chromium oxide, titanium oxide, rare earth elements, and internal markers, like indigestible acid detergent fibre, indigestible lignin, acid-insoluble ash (AIA) and $n$-alkanes, have been evaluated through the years in the search for a suitable marker. However, a marker that fulfils all the requirements of the ideal marker, namely, non-toxic, unaltered during its passage through the gut, no influence on the physiological processes in the digestive tract, closely associated to the undigested nutrient in question or flowing at an identical rate as the nutrient, and totally recovered in the faeces (Kotb and Luckey, 1972; De Silva, 1985; Marais, 2000), is yet to be found.

External markers must be mixed thoroughly with the feed or administrated to the animal, which may not be possible with large numbers of animals or animals under pasture conditions. Some feeds do not mix well with chemicals used as markers (Thonney et al., 1979; Rymer, 2000), and external markers might be excreted in a diurnal pattern, that precludes the use of grab faecal samples for determination of digestibility (Kotb and Luckey, 1972). Chromic oxide is probably the most 
commonly used external marker in nutritional studies. However, poor repeatability (Vohra, 1972), and increasing awareness of hazards involved in analyses of chromic oxide (De Silva, 1989), are some of the reasons for the search of alternative markers, especially in fish digestibility studies (Austreng et al., 2000).

Among the internal markers, natural $n$-alkanes, if present at sufficient concentrations in the diet, seem promising in digestibility studies (Marais, 2000). However, $n$-alkanes are not fully recovered in faeces, thus recovery rate has to be determined and incorporated in the digestibility estimation. Furthermore, analyses of $n$-alkanes require the use of capillary gas chromatography (Dove and Mayes, 1991), a costly method. The most widely internal marker used in digestibility studies is AIA (Table 1), a substance that has also been used to determine feed intake

TABLE 1

Studies where acid-insoluble ash had been used as marker to determine nutrient digestibility

\begin{tabular}{|c|c|c|}
\hline Species & Nutrient & Reference \\
\hline Beef cattle & $\begin{array}{l}\text { DM, OM, CP, energy, } \\
\text { DM, NDF, ADF } \\
\text { DM, OM, CP, energy, } \\
\text { NDF, ADF, hemicellulose }\end{array}$ & $\begin{array}{l}\text { Berger et al. (1981); Fulgoni (1984) } \\
\text { Barclay et al. (1986) } \\
\text { Schiere et al. (1989) } \\
\text { Huhtanen et al. (1994) } \\
\text { Ayangbile et al. (1993) } \\
\text { Staples et al. (1984) } \\
\text { Prado et al. (2001) }\end{array}$ \\
\hline Dairy cows & $\begin{array}{l}\text { DM, OM, CP, energy } \\
\text { NDF, ADF } \\
\text { hemicellulose } \\
\text { OM, CP, energy, starch }\end{array}$ & $\begin{array}{l}\text { Sharma et al. (1983) } \\
\text { Udén (1984) } \\
\text { Pettersson and Martinsson (1994) }\end{array}$ \\
\hline Sheep & DM, energy, ADF, cellulose & Sharma et al. (1983) \\
\hline Alpine ibex & $\begin{array}{l}\text { DM, OM, energy, CP } \\
\text { fat, crude fibre, NFE, } \\
\text { NDF, ADF }\end{array}$ & Bassano et al. (1999) \\
\hline White rhinos & Energy & Frape et al. (1982) \\
\hline Giraffes & $\mathrm{DM}, \mathrm{CP}, \mathrm{NDF}, \mathrm{ADF}$ & Clauss et al. (2001) \\
\hline Pigs & $\begin{array}{l}\text { DM, energy, cell walls } \\
\text { cellulose, hemicellulose } \\
\text { DM, CP, fat }\end{array}$ & $\begin{array}{l}\text { Varel et al. (1988) } \\
\text { Qin et al. (2002) }\end{array}$ \\
\hline Horses & $\begin{array}{l}\text { Energy } \\
\text { DM, NDF, ADF } \\
\text { hemicellulose, cellulose } \\
\text { OM, CP, energy } \\
\text { fat, NDF, ADF }\end{array}$ & $\begin{array}{l}\text { Frape et al. (1982) } \\
\text { Glade and Sist (1988) } \\
\text { Cuddeford et al. (1992) }\end{array}$ \\
\hline
\end{tabular}




\begin{tabular}{|c|c|c|}
\hline Species & Nutrient & Reference \\
\hline Dogs & DM, energy, nitrogen & Johnson et al. (1998) \\
\hline Cats & $\mathrm{DM}, \mathrm{CP}$, fat & Hesta et al. (2001) \\
\hline Tortoises & $\begin{array}{l}\text { Calcium, magnesium, } \\
\text { phoshorus }\end{array}$ & Liesegang et al. (2001) \\
\hline Broilers & $\begin{array}{l}\text { Energy } \\
\text { Amino acids } \\
\text { Energy, amino acids }\end{array}$ & $\begin{array}{l}\text { Schang et al. (1983); } \\
\text { Scott and Baldaji (1997); } \\
\text { Scott et al. (1998) } \\
\text { Hew et al. (1998) } \\
\text { Batal and Parsons (2002) }\end{array}$ \\
\hline Ducks & Energy & Martin et al. (1998) \\
\hline Ostrich & Energy & Farrell et al. (2001) \\
\hline Emu & Energy & Farrell et al. (2001) \\
\hline Trout & $\begin{array}{l}\text { DM, CP } \\
\text { DM, CP, energy, ash, lipid, } \\
\text { NFE, phosphorus, magnesium, } \\
\text { manganese, copper, } \\
\text { iron, zinc } \\
\text { Energy, fat, carbohydrate, } \\
\text { phosphorus, lysine }\end{array}$ & $\begin{array}{l}\text { Vandenberg and Noüe (2001) } \\
\text { Rodehutschord et al. }(2000,2002)\end{array}$ \\
\hline Tilapia & $\begin{array}{l}\mathrm{DM}, \mathrm{CP} \text {, energy } \\
\mathrm{CP} \text {, energy, fat }\end{array}$ & $\begin{array}{l}\text { Goddard and McLean (2001) } \\
\text { Sintayehu et al. (1996) }\end{array}$ \\
\hline Nile catfish & $\mathrm{CP}$, energy & Shabat (1993) \\
\hline Prawn & $\mathrm{CP}$ & Deering et al. (1996) \\
\hline Abalone & $\begin{array}{l}\mathrm{DM}, \mathrm{OM}, \mathrm{CP} \text {, energy, } \\
\text { fat, starch }\end{array}$ & Sales and Britz (2001a,b; 2002) \\
\hline
\end{tabular}

in cattle (Cortada and Velloso, 1987; Bodine et al., 2000), faecal output in sheep (Santos and Petit, 1996), as well as a solid marker in studies on the partition of site of digestion in cattle (Miller et al., 1986; Kraiem et al., 1990) and horses (Almeida et al., 1998), and for determining ileal digestibility in ducks (Martin et al., 1998), poultry (Ravindran et al., 1999) and pigs (Fan and Sauer, 2002).

The aim of this review is to present information on the definition and determination of AIA, to make a relative comparison of digestibility values derived through 
this method to values obtained with the use of the total collection method, and to describe the advantages and disadvantages connected with its use as marker in digestibility studies.

\section{DEFINITION AND DETERMINATION}

Acid-insoluble ash consists of indigestible mineral components, mainly silica. Silica has been used as early as 1874 as digestibility indicator (Kotb and Luckey, 1972), but is not widely used as marker at present due to its possible absorption from the gut and the risk, and, of contamination of feed with soil, especially with grazing animals (Rymer, 2000). Acid-insoluble ash contents of feeds and faeces are determined gravimetrically after drying, ashing, boiling of ash in hydrochloric acid $(\mathrm{HCl})$, filtering and washing of the hot hydrolysate, and re-ashing. Three variations to the original analytical method of Shrivastava and Talapatra (1962), consisting of the use of concentrated $\mathrm{HCl}$, evaporation to dryness, and ashing at $650^{\circ} \mathrm{C}$, are commonly in use. These are the adaptations by Vogtmann et al. (1975) in avian digestion studies, Van Keulen and Young (1977) in ruminants, pigs and horses, and Atkinson et al. (1984) in aquatic species (Table 2). In accordance to the method of Vogtmann et al. (1975), the ground sample has to be boiled in $\mathrm{HCl}$ before filtering and ashing. However, ashing of the sample prior to acid treatment removed the organic matter, thus reduces the acid concentration required (Van Keulen and Young, 1977). A higher ashing temperature to the method of Van Keulen and Young (1977) was introduced by Atkinson et al. (1984) to ensure complete combustion of the organic material in fish food with a high lipid content. Van Keulen and Young (1977) reported that, although dry matter digestibility of different diets were not significant different as from values determined with total collec-

TABLE 2

Analytical conditions of methods to determine acid-insoluble ash in feed and faeces

\begin{tabular}{lccc}
\hline & $\begin{array}{c}\text { Vogtmann } \\
\text { et al. }(1975)\end{array}$ & $\begin{array}{c}\text { Van Keulen and } \\
\text { Young (1977) }\end{array}$ & $\begin{array}{c}\text { Atkinson } \\
\text { et al. (1984) }\end{array}$ \\
\hline Feed, g & $10-12$ & 5 & $10-12$ \\
Faeces, g & 5 & 5 & $3-4$ \\
HCl, N & 4 & 2 & 2 \\
HCL, ml & 100 & 100 & 100 \\
Boiling time, min & 30 & 5 & 5 \\
Ashing, ${ }^{\circ} \mathrm{C}$ & 600 & $450^{1}$ & $600^{1}$ \\
Ashing, h & minimum 4 & overnight & 16 \\
\hline
\end{tabular}

${ }^{1}$ ashing before and after digestion in $\mathrm{HCl}$ 
tion in sheep by either the methods of Vogtmann et al. or Van Keulen and Young, Vogtmann et al.'s method produced digestibility values that were significant higher than values determined according to the method of Van Keulen and Young. Mean recovery of AIA in faeces followed the same tendency, although none of the methods differed significantly from total $(100 \%)$ recovery. Significantly lower AIA contents were found with Vogtmann et al.'s method compared to that of Van Keulen and Young in feed samples.

TABLE 3

Acid-insoluble ash content of some feed ingredients ( $\mathrm{g} / \mathrm{kg} \mathrm{DM})$

\begin{tabular}{lcll}
\hline Feed ingredient & AIA & Method & Reference \\
\hline Ground maize & 0.2 & Van Keulen and Young (1977) & Thonney (1981) \\
Lucerne hay & 3 & Van Keulen and Young (1977) & Sunvold and Cochran (1991) \\
$\begin{array}{l}\text { Lucerne hay } \\
\text { high water-stressed }\end{array}$ & 98 & Van Keulen and Young (1977) & Undersander et al. (1987) \\
medium water-stressed & 36 & Van Keulen and Young (1977) & Undersander et al. (1987) \\
low water-stressed & 37 & Van Keulen and Young (1977) & Undersander et al. (1987) \\
Brome hay & 21 & Van Keulen and Young (1977) & Sunvold and Cochran (1991) \\
Prairie hay & 45 & Van Keulen and Young (1977) & Sunvold and Cochran (1991) \\
Fish meal & 46 & Atkinson et al. (1984) & Sales (unpublished results) \\
Soyabean meal & 1 & Atkinson et al. (1984) & Sales (unpublished results) \\
Cottonseed meal & 2 & Atkinson et al. (1984) & Sales (unpublished results) \\
\hline
\end{tabular}

Unrealistic digestibility values with the use of AIA as marker has been assigned to analytical imprecision due to a low dietary and faecal AIA content that introduced a large margin of error to the calculation (Van Keulen and Young, 1977; Jones and De Silva, 1998). Thonney et al. (1985) recommended that the dietary AIA content should exceed $7.5 \mathrm{~g} / \mathrm{kg}$ on a dry matter (DM) basis in order to get accurate measurements and that appropriate diets should contain certain plant tissues that are high in AIA. The AIA content of some feed ingredients are presented in Table 3.

In several studies the AIA content of feeds has been increased by addition of exogenous sources of AIA. Thus, acid-insoluble ash could also be classified as an external marker. The most frequently used exogenous sources of AIA is a diatomic product called Celite, but sand (Tillman and Waldroup, 1988a,b), acid-washed sand (Tacon and Rodrigues, 1984), volcanic ash (Thonney, 1981), silica (Cheng and Coon, 1990), Sipernat (Degussa AG, Frankfurt, Germany) (Rodehutscord et al., 1996) and bentonite (Sales and Britz, 2001a), have also been used. Although the addition of exogenous AIA sources will improve precision of measurement (Thonney, 1981), McCarthy et al. (1974) found that when Celite was added to pig diets, the AIA method underestimated digestibility of nitrogen and energy in com- 
parison to total collection, while comparable values were found between methods when Celite was excluded. They suggested that some Celite may be partly lost during feeding. A similar trend with addition of bentonite was reported in studies with abalone (Sales and Britz, 2001a). Tacon and Rodrigues (1984) found that precision decreased when dietary AIA concentration was increased to $20 \mathrm{~g} / \mathrm{kg}$ with acid-washed sand in trout, while the opposite (increased precision) was found with the addition of a product of fine diatoms to pig diets (Jongbloed et al., 1991) and Celite to broiler diets (Scott and Baldaji, 1997).

Although Schang et al. (1983) stated that it is reasonable to assume that the flow of AIA through the alimentary tract of poultry reflects the passage of undigested feed residues, Wetherbee and Gruber (1993) reported differential intestinal passage rates for AIA and feed in the lemon shark. Also, Cheng and Coon (1990) postulated that, in the presence of a high dietary level of silica $(>0.2 \%)$, the intestinal flow of acid-insoluble ash might fail to reflect the passage of undigested feed. Thus, when adding ash or silica into the feed to enhance analytical accuracy of AIA, consideration should always be given to the possible inflation in the digestibility due to higher AIA intake (Cheng and Coon, 1990). Interference of added sand or other materials as primary source of AIA, instead of aiding, as intended, might happen. Determined AIA content in the feed might be lower than the actual value, or higher in faeces than was actually present (Tillman and Waldroup, 1988a).

\section{RECOVERY RATE}

Total faecal recovery, the most important criterion that must be met by any marker that is used in digestibility studies, is presented in Table 4 as the mean recovery rate of AIA determined with several diets.

Of 35 recovery rates presented in Table 4, 18 were within a five percentage unit range from $100 \%$ recovery, and 25 within 10 percentage units. A recovery rate of $192 \%$ was found when beef cattle were fed on lucerne hay, with a value of 101 $\%$ when fed prairie hay (Sunvold and Cochran, 1991). A similar variable recovery rate of 97 to $183 \%$ were reported in pigs fed different maize based diets (Bakker and Jongbloed, 1994). The inconsistencies found in the above studies could be due to a low AIA content in feeds that will decrease analytical precision, soil ingestion by animals (Galyean et al., 1986), soil and dust in diets or faeces (Piaggio et al., 1991; Marais, 2000), or inaccurate feed sampling for AIA analysis. Environmental influences (water-stress) on lucerne had an influence on recovery rate of AIA found in sheep, leading to differences in dry matter, organic matter and cellulose digestibility coefficients between the total collection method and AIA marker method (Undersander et al., 1987). Except for three studies in Table 4 (Undersander et al., 1987; Piaggo et al., 1991; Zeoula et al. 1994), recovery rate of AIA was 
TABLE 4

Recovery rate of acid-insoluble ash with different species, \%

\begin{tabular}{|c|c|c|c|}
\hline Species & Diet & Recovery & Reference \\
\hline \multirow[t]{6}{*}{ Beef cattle } & Concentrate, grass hay & 100 & Thonney et al. (1979) \\
\hline & Roughage, concentrate & 127 & Wilson and Winter (1984) \\
\hline & Lucerne hay & 192 & Sunvold and Cochran (1991) \\
\hline & Brome hay & 106 & Sunvold and Cochran (1991) \\
\hline & Prairie hay & 101 & Sunvold and Cochran (1991) \\
\hline & Fescue hay & 91 & Bohnert et al. (2000) \\
\hline \multirow[t]{5}{*}{ Dairy cows } & Silage, hay & 119 & Nishino et al. (1979) \\
\hline & Hay & & \\
\hline & account for orts & 99 & Block et al. (1981) \\
\hline & discard orts & 118 & Block et al. (1981) \\
\hline & Hay, concentrate & 100 & Ohajuruka and Palmquist (1991) \\
\hline Buffaloes & Urea-ensiled rice straw & 105 & Sriwattanasombat and Wanapat (1983) \\
\hline \multirow[t]{16}{*}{ Sheep } & Lucerne, grains & & \\
\hline & 2N HCl-method & 96 & Van Keulen and Young (1977) \\
\hline & 4N HCl method & 103 & Van Keulen and Young (1977) \\
\hline & Maize plants & & \\
\hline & account for orts & 100 & Block et al. (1981) \\
\hline & discard orts & 104 & Block et al. (1981) \\
\hline & Hay & & \\
\hline & account for orts & 101 & Block et al. (1981) \\
\hline & discard orts & 98 & Block et al. (1981) \\
\hline & Pelleted feed & 99 & Piccolo et al. (1986) \\
\hline & Lucerne hay & & \\
\hline & high water-stressed & 90 & Undersander et al. (1987) \\
\hline & medium water-stressed & 97 & Undersander et al. (1987) \\
\hline & low water-stressed & 117 & Undersander et al. (1987) \\
\hline & Lucerne hay & 84 & Piaggio et al. (1991) \\
\hline & $\begin{array}{l}\text { Soyabeans, oats hay } \\
\text { free intake } \\
\text { restricted intake }\end{array}$ & $\begin{array}{l}151 \\
115\end{array}$ & $\begin{array}{l}\text { Zeoula et al. (1994) } \\
\text { Zeoula et al. (1994) }\end{array}$ \\
\hline Goats & Rice straw, concentrate & 88 & Trung et al. (1987) \\
\hline \multirow[t]{5}{*}{ Pigs } & Barley based & 93 & Wünsche et al. (1984); \\
\hline & & 91 & Moughan et al. (1991) \\
\hline & Maize, soya, apple pomace & 97 & Furuya et al. (2001) \\
\hline & Cereal based & 100 & Kavanagh et al. (2001) \\
\hline & Wheat middlings & 91 & Yin et al. (2001) \\
\hline \multirow[t]{2}{*}{ Horses } & Grass, sugarcane & 101 & Pereira and Queiroz (1997) \\
\hline & Grass, hay & 101 & Araújo et al. (2000) \\
\hline Dogs & Maize, animal meal & 96 & Johnson et al. (1998) \\
\hline Ostriches & Concentrate, lucerne & 127 & Nizza and Meo (2000) \\
\hline Humans & Celite & 92 & Rowan et al. (1991) \\
\hline
\end{tabular}


around $100 \%$ for all studies on sheep. The recovery rate of over $100 \%$ in ostriches was probably attributed to their feeding habits of grit intake, thus accumulating siliceous particles in their proventriculum (Nizza and Meo, 2000). However, the method of Vogtmann et al. (1975), used in the latter study, resulted in higher recovery rates than the method of Van Keulen and Young (1977).

When feeding cattle and sheep ad libitum, the AIA method may be questionable unless feed offered and orts are weighed regularly and sampled for AIA con-

TABLE 5

Digestibility values derived through acid-insoluble ash as marker in comparison to values obtained with total collection (TC)

\begin{tabular}{|c|c|c|c|}
\hline Species & Nutrient & $\begin{array}{l}\text { Compared } \\
\text { with TC }\end{array}$ & Reference \\
\hline \multirow{4}{*}{$\begin{array}{c}\text { Beef cattle } \\
\text { silage diet } \\
\text { grain diet }\end{array}$} & $\mathrm{DM}$ & Overestimate & Wilson and Winter (1984) \\
\hline & $\mathrm{DM}$ & Similar & Thonney et al. (1985) \\
\hline & $\mathrm{DM}$ & Underestimate & Thonney et al. (1985) \\
\hline & $\mathrm{OM}$ & Similar & Sunvold and Cochran (1991) \\
\hline \multirow[t]{2}{*}{ Dairy cows } & $\mathrm{CP}$ & Overestimate & Nishino et al. (1979) \\
\hline & $\mathrm{DM}$ & Similar & Ohajuruka and Palmquist (1991) \\
\hline Buffaloes & $\mathrm{DM}, \mathrm{CP}, \mathrm{NDF}$ & Similar & Sriwattanasombat and Wanapat (1983) \\
\hline Bison & $\begin{array}{l}\text { DM, CP, energy, } \\
\text { crude fibre, NDF, } \\
\text { ADF, } \\
\text { hemicellulose, } \\
\text { lignin }\end{array}$ & Overestimate & Hawley et al. (1981) \\
\hline \multirow[t]{10}{*}{ Sheep } & $\mathrm{DM}$ & Similar & Van Keulen and Young (1977) \\
\hline & $\mathrm{DM}$ & Underestimate & Aguilar et al. (1983) \\
\hline & $\mathrm{DM}$ & Similar & Thonney et al. (1985) \\
\hline & $\mathrm{OM}$ & Underestimate & Penning and Johnson (1983) \\
\hline & $\mathrm{OM}$ & Underestimate & Piaggio et al. (1991) \\
\hline & $\mathrm{DM}, \mathrm{OM}, \mathrm{CP}$ & & \\
\hline & NDF, ADF & Similar & Cheva-Isarakul and Saengdee (1986) \\
\hline & DM, nitrogen, & & \\
\hline & ADF, NDF & Similar & Santos and Petit (1996) \\
\hline & $\mathrm{CP}$ & Similar & Nishino et al. (1979) \\
\hline \multirow[t]{3}{*}{ Goats } & $\begin{array}{l}\text { DM, OM, CP, } \\
\text { energy, }\end{array}$ & & \\
\hline & $\begin{array}{l}\text { NDF, ADF, } \\
\text { cellulose }\end{array}$ & Similar & Carvalho et al. (1992) \\
\hline & $\mathrm{DM}$ & Underestimate & Resende et al. (1996) \\
\hline
\end{tabular}


continue

\begin{tabular}{|c|c|c|c|}
\hline Species & Nutrient & $\begin{array}{l}\text { Compared } \\
\text { with TC } \\
\end{array}$ & Reference \\
\hline \multirow[t]{4}{*}{ Pigs } & $\mathrm{DM}$ & Similar & Rowan et al. (1991) \\
\hline & DM, OM, energy & Similar & Moughan et al. (1991) \\
\hline & $\mathrm{DM}, \mathrm{OM}, \mathrm{CP}$ & Similar & Borgmann et al. (1985) \\
\hline & DM, CP & Similar & Furuya et al. (2001) \\
\hline \multirow[t]{2}{*}{ Mong Cai } & DM, OM, & & \\
\hline & nitrogen, NDF & Overestimate & Ly et al. (2002) \\
\hline \multirow{3}{*}{ Large White } & $\begin{array}{l}\mathrm{DM}, \mathrm{OM} \\
\text { nitrogen NDF }\end{array}$ & Similar & I y et al (2002) \\
\hline & $\begin{array}{l}\text { nitrogen, NDF } \\
\text { OM CP }\end{array}$ & Overestimate & $\begin{array}{l}\text { Ly et al. (2002) } \\
\text { Bakker and Jon obloed (1994) }\end{array}$ \\
\hline & Energy & Similar & Kavanagh et al. (2001) \\
\hline 12 weeks & Nitrogen, energy & Similar & Yen et al. (1983) \\
\hline \multirow[t]{2}{*}{19 weeks } & Nitrogen, energy & Underestimate & Yen et al. (1983) \\
\hline & $\mathrm{CP}$, amino acids & Similar & Wiesemuller et al. (1981) \\
\hline \multirow[t]{6}{*}{ Horses } & $\mathrm{DM}$ & Similar & Orton et al. (1985) \\
\hline & Nitrogen, energy & Similar & Sutton et al. (1977) \\
\hline & ADF, NFE & Similar & Cuddeford and Hughes (1990) \\
\hline & DM, OM, CP, & & \\
\hline & crude fibre, fat, & & \\
\hline & $\begin{array}{l}\text { ADr, } \\
\text { NDF, NFE }\end{array}$ & Similar & Miraglia et al. (1999) \\
\hline Kowari & $\mathrm{DM}$ & Overestimate & Trouten-Redford et al. (1995) \\
\hline Laying hens & $\mathrm{Ca}$ & Overestimate & Cheng and Coon (1990) \\
\hline \multirow[t]{3}{*}{ Broilers } & \multirow{3}{*}{$\begin{array}{l}\text { Energy } \\
\text { Fatty acids } \\
\text { Energy, amino } \\
\text { acids }\end{array}$} & Underestimate & Vogtmann et al. (1975) \\
\hline & & Similar & Vogtmann et al. (1975) \\
\hline & & Overestimate & Tillman and Waldroup (1988a;b) \\
\hline \multirow[t]{2}{*}{ Ducks } & DM, nitrogen, & & \\
\hline & $\mathrm{Ca}, \mathrm{P}$ & Underestimate & Farrell and Martin (1998) \\
\hline Barbary partridge & $\mathrm{OM}, \mathrm{CP}$, energy & Overestimate & Moniello et al. (2001) \\
\hline Ostriches & $\begin{array}{l}\text { DM, OM, CP, } \\
\text { energy, fat }\end{array}$ & Overestimate & Nizza and Meo (2000) \\
\hline Dogs & $\begin{array}{l}\mathrm{DM}, \mathrm{CP} \text {, energy, } \\
\text { fat, NFE }\end{array}$ & Similar & Lôbo et al. (2001) \\
\hline Humans & $\mathrm{DM}$ & Similar & Rowan et al. (1991) \\
\hline Abalone & $\mathrm{DM}$ & Similar & Sales and Britz (2001a) \\
\hline
\end{tabular}


tent, a sufficiently large number of animals is used, and diets are adequately mixed to limit feed selection and sorting (Block et al., 1981). The importance of taking orts into account in determination of digestibility when using AIA as marker is clearly illustrated in Table 4 in that mean values were closer to $100 \%$ recovery when taking orts into account than when disregarding orts. An overestimation of $118 \%$ for recovery rate was found when disregarding orts in dairy cows fed on hay. Disregarding of orts led to large deviations from $100 \%$ recovery when orts represented more than $10 \%$ of feed offered, and were caused by higher AIA contents in orts than in feed offered (Block et al., 1981).

\section{COMPARISON OF THE ACID-INSOLUBLE ASH MARKER METHOD WITH THE TOTAL COLLECTION METHOD}

In Table 5 digestibility values derived with the AIA method is compared to values obtained through the total collection method. This relative comparison is presented according to statistical differences between methods as obtained in the mentioned studies.

Of 45 studies summarized in Table 5, 26 presented similar results between methods, while in nine the AIA method underestimated and 10 overestimated digestibility compared to the total collection method. In horses, and most studies with pigs, similar results were found between values determined with either total collection or AIA as marker. McCarthy et al. (1977) and Yen et al. (1983) stated that overestimation by total collection in heavier and older pigs could have been the result of failure to achieve total faecal collection in big metabolism cages. Acid-insoluble ash has caused overestimations compared to total collection in most studies with avian species (laying hens, broilers, partridges, ostriches) presented in Table 5. A possible explanation could be the use of the method of Vogtman et al. (1975) to determine AIA in avian digestion studies, a method that, compared to other methods, is leading to higher digestibility values, as earlier described.

Diurnal and daily variations in faecal AIA content were insignificant in poultry (Vogtmann et al., 1975), sheep (Van Keulen and Young, 1977; Thonney et al., 1985), pigs (McCarthy et al. 1977), cattle (Thonney et al., 1985), and horses (Cuddeford and Hughes, 1990), making the use of grab sampling possible. When using grab sampling, especially with diets that have a low AIA content, samples must be obtained from a number of animals over several days (Thonney, 1981; Thonney et al., 1985). More variation in metabolizability of energy and digestibility of amino acids has been reported in growing chickens (Tillman and Waldroup, 1988a,b) when applying the AIA method compared to total collection. However, the opposite (less variation when using the AIA method) has been found in ducks (Farrell and Martin, 1998). 


\section{CONCLUSIONS AND RECOMMENDATIONS}

Acid-insoluble ash is a marker that could be used in digestibility studies in animals as an alternative to the total collection method. More natural housing could be applied, that will not only give a more reliable measurements of the animals' productive status, but will also be in accordance to animal welfare considerations. The AIA method, in accordance to the use of the marker technique to determine digestibility, has the advantage that grab samples could be taken from animals, resulting in obtaining samples from free-living animals before any chemical changes in faeces could occur. Furthermore, animals that have a social structure could be kept in groups for digestibility studies.

Special care should be taken when applying this method to grazing animals and outdoor pigs where ingestion of soil could occur, or for avain species like ratites and pigeons, where ingestion of grit could led to accumulation of siliceous components in the digestive tract. Soil and dust in feed and laboratories should be eliminated. When using grab sampling, samples have to be taken from several animals on different days, especially when the AIA contents of diets are low, and the AIA contents of orts have to be accounted for. The use of substances to increase the AIA content of feeds must be considered with great care.

The use of AIA as marker in digestibility studies is easy and simple in that the method of determination is simple and does not involve costly equipment or chemicals, but difficult in that a high degree of precision and skill is needed during analysis for it. Most digestibility studies where AIA had not met the expectations of a suitable marker did not attribute this to marker failure, but to analytical inaccuracy due mainly to low AIA contents. Suggestions for further research would be to evaluate the different methods available to determine AIA across feeds, faeces, and laboratories, and standardized (sample size, ashing temperature, amount of wash water) it to one reliable method in order to get high repeatability.

\section{REFERENCES}

Aguilar A., Chel L., Castellanos A., 1983. A comparative study of methods to determine the digestibility of feedstuffs for ruminants and monogastrics. Trop. Anim. Prod. 8, 72-73

Almeida de F.Q., Campos Valadares Filho de S., Silva da J.F.C., Alvarenga R.C., Cecon P.R., Leão M., 1998. Ileal flow of dry matter obtained with external and internal markers in equines (in Portuguese). Rev. Soc. Bras. Zoot. 27, 513-520

Araújo K.V., Lima J.A., Fialho E.T., Miyagi E.S., 2000. Comparison among the internal markers and the total collection method in the determination of the forage nutrient digestibilities in equines (in Portuguese). Rev. Soc. Bras. Zoot. 29, 745-751

Atkinson J.L., Hilton J.W., Slinger S.J., 1984. Evaluation of acid-insoluble ash as an indicator of feed digestibility in rainbow trout (Salmo gairdneri). Can. J. Fisheries Aquat. Sci. 41, 1384-1386 
Austreng E., Storebakken T., Thomassen M.S., Refstie S., Thomassen Y., 2000. Evaluation of selected trivalent metal oxides as inert markers used to estimate apparent digestibility in salmonids. Aquaculture 188, 65-78

Ayangbile O.A., Tallam S.K., Surtan M.S., 1993. Processing of slaughterhouse blood and poultry litter and the effects on nutrient digestibility of steers. Anim. Feed Sci. Tech. 40, 153-164

Bakker G.C.M., Jongbloed A.W., 1994. The effect of housing system on apparent digestibility in pigs, using the classical and marker (chromic oxide, acid-insoluble ash) techniques, in relation to dietary composition. J. Sci. Food Agr. 64, 107-115

Barclay R.A., Faulkner D.B., Fahey G.C. Jr., Cmarik G.F., 1986. Effects of salinomycin on performance characteristics and apparent dry matter digestion by grazing beef steers. Nutr. Rep. Int. 33, 43-54

Bassano B., Bergero D., Tarantola M., Martys M., 1999. Diet digestibility in captive Alpine ibex (Capra ibex ibex). Zoot. Nutr. Anim. 25, 43-47

Batal A.B., Parsons C.M., 2002. Effects of age on nutrient digestibility in chicks fed different diets. Poultry Sci. 81, 400-407

Berger L.L., Ricke S.C., Fahey G.C. Jr., 1981. Comparison of two forms and two levels of lasalocid with monensin on feedlot cattle performance. J. Anim. Sci. 53, 1440-1445

Bergero D., Peiretti P.G., Cola E., 2002. Intake and apparent digestibility of perennial ryegrass haylages fed to ponies either at maintenance or at work. Livest. Prod. Sci. 77, 325-329

Block E., Kilmer L.H., Muller L.D., 1981. Acid insoluble ash as a marker of digestibility for sheep fed corn plants or hay and for lactating dairy cattle fed hay ad libitum. J. Anim. Sci. 52, 1164-1169

Bodine T.N., Purvis H.T. II, Cox, D.A., 2000. Effects of supplemental energy and degradable intake protein on grazing behavior, forage intake, digestion and performance of steers grazing winter range. Animal Science Research Report - Agricultural Experiment Station, Oklahoma State University, No. P-980 (USA), pp. 33-39

Bohnert D.W., Harmon D.L., Larson B.T., 2000. Evaluation of four internal markers and an intra-ruminal chromium-releasing device for use in predicting diet digestibility and intake in beef steers. Kentucky Beef Cattle Research Report, Agricultural Experimental Station, College of Agriculture, University of Kentucky, KY (USA), pp. 29-30

Borgmann E., Wünsche J., Hennig U., Kreienbring F., Bock H.D., 1985. Estimation of nutrient digestibility in pigs with HCl-insoluble ash as indicator (in German). Tierernähr. Futt. 14, 143-148

Carvalho de F.F.R., Queiros de A.C., Rodrigues M.T., Fontes de C.A., 1992. Use of internal markers to estimate digestibility of nutrients for lactating goats fed ad libitum (in Portuguese). Rev. Soc. Brasil. Zoot. 21, 270-278

Cheng T.K., Coon C.N., 1990. Research Note: Calcium digestibility studies utilizing acid-insoluble ash measurements. Poultry Sci. 69, 2228-2230

Cheva-Isarakul B., Saengdee C., 1986. Voluntary intake, nutrient digestibility and nitrogen balance in sheep fed sorghum. Ruminant feeding systems utilizing fibrous agricultural residues - 1986, Proceedings of the 6th Annual Workshop of the Australian-Asian Fibrous Agricultural Residues Research Network, Los Baños, 1-3 April, International Development Program of Australian Universities and Colleges Ltd., Canberra (Australia), pp. 133-138

Clauss M., Lechner-Doll M., Flach E.J., Tack C., Hatt J-M., 2001. Comparative use of four different marker systems for the estimation of digestibility and low food intake in a group of captive giraffes (Giraffa camelopardalis). Zoo Biol. 20, 315-329

Cortada C.N.M., Velloso L., 1987. Acid insoluble ash used to determine dry matter intake by cattle (in Portuguese). Rev. Fac. Med. Vet. Zoot. Univ. Sao Paulo 24, 61-64

Cuddeford D., Hughes D., 1990. A comparison between chromium-mordanted hay and acid-insoluble ash to determine apparent digestibility of a chaffed, molassed hay/straw mixture. Equine Vet. J. 22, 122-125 
Cuddeford D., Woodhead A., Muirhead R., 1992. A comparison between the nutritive value of short-cutting cycle, high temperature-dried alfalfa and timothy hay for horses. Equine Vet. J. 24, 84-89

Deering M.J., Hewitt D.R., Sarac H.Z., 1996. A comparison of inert markers used to estimate protein digestibility in the leader prawn Penaeus monodon. J. World Aquacult. Soc. 27, 103-106

De Silva S.S., 1985. Evaluation of the use of internal and external markers in digestibility studies. In: C.Y. Cho, C.B. Cowey, T. Watanabe (Editors), Finfish Nutrition in Asia. Methodological Approaches to Research and Development, International Development Research Centre, Ottawa (Canada), pp. 96-102

De Silva S.S., 1989. Digestibility evaluations of natural and artificial diets. In: S.S. De Silva (Editor), Proceedings of the Third Asian Fish Nutrition Network Meeting, Fish Nutrition Research in Asia. Asian Fisheries Society, Special Publication 4, Manila (Philippines), pp. 36-45

Dove H., Mayes R.W., 1991. The use of plant wax alkanes as marker substances in studies of the nutrition of herbivores: a review. Aust. J. Agr. Res. 42, 913-952

Fan M.Z., Sauer W.C., 2002. Determination of true ileal amino acid digestibility and the endogenous amino acid outputs associated with barley samples for growing-finishing pigs by regression analysis technique. J. Anim. Sci. 80, 1593-1605

Farrell D.J., Martin E.A., 1998. Strategies to improve the nutritive value of rice bran in poultry diets. III. The addition of inorganic phosphorus and a phytase to duck diets. Brit. Poultry Sci. 39, 601-611

Farrell D.J., Sales J., Perez-Maldonado R., Kent P., Shermer M., Mannion P.F., 2001. The apparent metabolisable energy of diets with different sources of fibre when fed to emus, ostriches and cockerels. In: A. Chwalibog, K. Jakobsen (Editors). Proceedings of the $15^{\text {th }}$ Symposium on Energy Metabolism in Animals, Copenhagen (Denmark). EAAP Publication No. 103, Wageningen Press, Wageningen, pp. 141-143

Frape D.L., Tuck M.G., Sutcliffe N.H., Jones D.B., 1982. The use of inert markers in the measurement of the digestibility of cubed concentrates and of hay given in several proportions to the pony, horse and white rhinoceros (Diceros simus). Comp. Biochem. Physiol. 72A, 77-83

Fulgoni V. L., 1984. The relationship of body size, lactation or gestation with ration intake, nutrient digestibility and digestible nutrient intake in beef cattle. Diss. Abstr. Int. B (Sci. Eng.) 45, 3-4

Furuya S., Yamamoto A., Itoh M., Aoki Y., 2001. Use of acid-insoluble ash added with celite as a marker for determining digestibility in pigs (in Japanese). Jpn. J. Swine Res. 38, 171-176

Galyean M.L., Krysl L.J., Estell R.E., 1986. Marker-based approaches for estimation of fecal output and digestibility in ruminants. In: F.N. Owens (Editor). Feed Intake by Beef Cattle. Symposium, Oklahoma Agricultural Experimental Station, MP-121, Stillwater (USA), pp. 96-113

Glade M.J., Sist M.D., 1988. Dietary yeast culture supplementation enhances urea recycling in the equine large intestine. Nutr. Rep. Int. 37, 11-17

Goddard J.S., McLean E., 2001. Acid-insoluble ash as an inert reference material for digestibility studies in tilapia, Oreochromis aureus. Aquaculture 194, 93-98

Hatt J.-M., Gisler R., Mayes R.W., Lechner-Doll M., Clauss M., Liesegang A., Wanner M., 2002. The use of dosed and herbage $\mathrm{N}$-alkanes as markers for the determination of intake, digestibility, mean retention time and diet selection in Galapagos tortoises (Geochelone nigra). Herpetol. J. 12, 45-54

Hawley A.W.L., Peden D.G., Stricklin W.R., 1981. Bison and Hereford steer digestion of sedge hay. Can. J. Anim. Sci. 61, 165-174

Hesta M., Janssens G.P.J., Debraekeleer J., De Wilde R., 2001. The effect of oligofructose and inulin on faecal characteristics and nutrient digestibility in healthy cats. J. Anim. Physiol. Anim. Nutr. $85,135-141$ 
Hew L.I., Ravindran V., Mollah Y., Bryden W.L., 1998. Influence of exogenous xylanase supplementation on apparent metabolisable energy and amino acid digestibility in wheat for broilers. Anim. Feed Sci. Tech. 75, 83-92

Huhtanen P., Kaustell K., Joakkola S., 1994. The use of internal markers to predict total digestibility and duodenal flow of nutrients in cattle given six diets. Anim. Feed Sci. Tech. 48, 211-227

Johnson M.L., Parsons C.M., Fahey G.C. Jr., Merchen N.R., Aldrich C.G., 1998. Effects of species raw material source, ash content, and processing temperature on amino acid digestibility of animal by-product meals by cecectomized roosters and ileally cannulated dogs. J. Anim. Sci. 76, 1112-1122

Jones P.L., De Silva S.S., 1998. Comparison of internal and external markers in digestibility studies involving the Australian freshwater crayfish, Cherax destructor Clark (Decapoda, Parastacidae). Aquac. Res. 29, 487-493

Jongbloed A.W., Bakker J.G.M., Goedhart P.W., Krol-Kramer F., 1991. Evaluation of chromic oxide with lower concentration and of $\mathrm{HCl}$-insoluble ash as markers for measuring overall apparent digestibility of some dietary nutrients for pigs. Proceedings of the 5th International Symposium on Digestive Physiology in Pigs, Wageningen, (The Netherlands), pp. 325-329

Kabir N.M.J., Wee K.L., Maguire G., 1998. Estimation of apparent digestibility coefficients in rainbow trout (Oncorhynchus mykiss) using different markers. Aquaculture 167, 259-272

Kavanagh S., Lynch P.B., O’Mara F., Caffrey P.J., 2001. A comparison of total collection and marker technique for the measurement of apparent digestibility of diets for growing pigs. Anim. Feed Sci. Tech. 89, 49-58

Kotb A.R., Luckey T.D., 1972. Markers in nutrition. Nutr. Abstr. Rev. 42, 813-845

Kraiem K., Garrett J.E., Meiske J.C., Goodrich R.D., Marten G.C., 1990. Influence of method of forage preservation on fibre and protein digestion in cattle given lucerne, birdsfoot trefoil and sainfoin. Anim. Prod. 50, 221-230

Liesegang A., Hatt J-M., Nijboer J., Forrer R. Wanner M., Isenbügel E., 2001. Influence of different dietary calcium levels on the digestibility of $\mathrm{Ca}, \mathrm{Mg}$, and $\mathrm{P}$ in captive-born juvenile Galapagos giant tortoises (Geochelone nigra). Zoo Biol. 20, 367-374

Lõbo Júnior M.F., Rezende A.S.C., Saliba E.O.S., Sampaio I.B.M., 2001. Determination of apparent digestibility coefficients either by markers or total fecal collection techniques in dogs (in Portuguese). Arq. Bras. Med. Vet. Zoot. 53, 691-694

Ly J., Ty C., Samkol P., 2002. Studies on the use of acid insoluble ash as inert marker in digestibility trials with Mong Cai pigs. Lives. Res. Rural Develop. 14, Issue 5 (On-line edition)

Marais J.P., 2000. Use of markers. In: J.P.F. Mello (Editor). Farm Animal Metabolism and Nutrition. CABI International, Wallingford, Oxon (UK), pp. 255-277

Martin E.A., Nolan J.V., Nitsan Z., Farrell D.J., 1998. Strategies to improve the nutritive value of rice bran in poultry diets. IV. Effects of addition of fish meal and a microbial phytase to duckling diets on bird performance and amino acid digestibility. Brit. Poultry Sci. 39, 612-621

McCarthy, J.F., Aherne, F.X., Okai, D.B., 1974. Use of $\mathrm{HCl}$ insoluble ash as an index material for determining apparent digestibility with pigs. Can. J. Anim. Sci. 54, 107-109

McCarthy J.F., Bowland J.P., Aherne F.X., 1977. Influence of method upon the determination of apparent digestibility in the pig. Can. J. Anim. Sci. 57, 131-135

McNab J.M., 2000. Rapid metabolizable energy assays. In: J.P.F. Mello (Editor). Farm Animal Metabolism and Nutrition. CABI International, Wallingford, Oxon (UK), pp. 307-315

Miller B.L., Meiske J.C., Goodrich R.D., 1986. Effects of dietary additives on B-vitamin production and absorption in steers. J. Anim. Sci. 62, 484-496

Miraglia N., Bergero D., Bassano B., Tarantola M., Ladetto G., 1999. Studies of apparent digestibility in horses and the use of internal markers. Livest. Prod. Sci. 60, 21-25 
Moniello G., Pinna W., Nizza A., Stanco G., Solinas I.L., 2001. Digestion capabilities and estimation of metabolisable energy of diets in relation to their chemical components in Barbary partridge (Alectoris Barbara) (in Italian). Riv. Avicolt. 70, 37-40

Moughan P.J., Smith W.C., Schrama J., Smits C., 1991. Chromic oxide and acid-insoluble ash as faecal markers in digestibility studies with young growing pigs. N.Z. J. Agr. Res. 34, 85-88

Nishino S., Kondo S., Ogino K., 1979. Determinations on acid-insoluble ash as index substance of digestion trials with sheep and lactating cows (in Japanese). J. Coll. Dairying 8, 23-30

Nizza A., Meo de C., 2000. Determination of apparent digestibility coefficients in 6-, 12-and 18week-old ostriches. Brit. Poultry Sci. 41, 518-520

Ohajuruku O.A., Palmquist D.L., 1991. Evaluation of $n$-alkanes as digesta markers in dairy cows. J. Anim. Sci. 69, 1726-1732

Orton R.K., Hume I.D., Leng R.A., 1985. Effects of exercise and level of dietary protein on digestive function in horses. Equine Vet. J. 17, 386-390

Penning P.D., Johnson R.H., 1983. The use of internal markers to estimate herbage digestibility and intake. 1. Potentially indigestible cellulose and acid insoluble ash. J. Agr. Sci. 100, 127-131

Pereira J.C., Queiroz de A.C., 1997. Apparent digestibility in horses fed different proportions of elephant grass (Pennisetum purpureum, Schum) and sugarcane (Succharum officinarum, L.) (in Portuguese). Rev. Soc. Bras. Zoot. 26, 105-110

Pettersson T., Martinsson K.A., 1994. Digestibility of whole or rolled ensiled barley grain fed to heifers or lactating cows. Swed. J. Agr. Res. 24, 109-113

Piaggio L.M., Pratas Ê.R., Pires F.F., Ospina H., 1991. Evaluation of acid insoluble ash, nondigestible acid detergent fibre and nondigestible acid detergent lignin as internal markers of digestibility (in Portuguese). Rev. Soc. Bras. Zoot. 20, 306-312

Piccolo V., Nizza A., Lella T., 1986. Observations on different methods of estimating apparent digestibility coefficients in wethers (in Italian). Zoot. Nutr. Anim. 12, 295-299

Prado I.N., Zeoula L.M., Vinocur K., Medroni S., Nascimento W.G., 2001. Reduction of bromatological analyses in feed intake, feed conversion and apparent digestibility for feedlot heifers (in Portuguese). Acta Scient. 23, 1069-1073

Qin G.X., Xu L.M., Jiang H.L., Poel van der A.F.B., Bosch M.W., Verstegen M.W.A., 2002. The effects of Chinese and Argentine soyabeans on nutrient digestibility and organ morphology in Landrace and Chinese Min pigs. Asian-Austr.) J. Anim. Sci. 15, 555-564

Ravindran V., Hew L.I., Ravindran G., Bryden W.L., 1999. A comparison of ileal digesta and excreta analysis for the determination of amino acid digestibility in food ingredients for poultry. Brit Poultry Sci. 40, 266-274

Resende de K.T., Furlan C.L., Costa R.G., Sugohara A., Vascondelos V.R., Carvalho de F.F.R., Guideli C., 1996. Use of chromated collagen as an indicator in digestion studies in goats (in Portuguese). Rev. Soc. Bras. Zoot. 25, 806-813

Rodehutscord M., Borchert F., Gregus Z., Pfeffer E., 2002. Availability and utilisation of free lysine in rainbow trout (Oncorhynchus mykiss). 2. Comparison of L-lysine-HCl and L-lysine sulphate. Aquaculture 187, 177-183

Rodehutscord M., Faust M., Lorenz H., 1996. Digestibility of phosphorus contained in soybean meal, barley, and different varieties of wheat, without and with supplemental phytase fed to pigs and additivity of digestibility in a wheat-soy-bean-meal diet. J. Anim. Physiol. Anim. Nutr. 75, 40-48

Rodehutscord M., Gregus Z., Pfeffer E., 2000. Effect of phosphorus intake on faecal and non-faecal phosphorus excretion in rainbow trout (Oncorhynchus mykiss) and the consequences for comparitive phosphorus availability. Aquaculture 188, 383-398

Rowan A.M., Moughan P.J., Wilson M.N., 1991. Acid-insoluble ash as a marker compound for use in digestibility studies with humans. J. Sci. Food Agr. 54, 269-274 
Rymer C., 2000. The measurement of forage digestibility in vivo. In: D.I. Givens, E. Owen, R.F.E. Axford, H.M. Ohmed (Editors). Forage Evaluation in Ruminants. CABI International, Wallingford, Oxon (UK), pp. 113-132

Sales J., Britz P.J., 2001a. Evaluation of the reference diet substitution method for determination of apparent nutrient digestibility coefficients of feed ingredients for South African abalone ( $\mathrm{Ha}$ liotis midae L.). Aquaculture 207, 113-123

Sales J., Britz P.J., 2001b. Evaluation of different markers to determine apparent nutrient digestibility coefficients of feed ingredients for South African abalone, (Haliotis midae L.). Aquaculture 202, 113-129

Sales J., Britz P.J., 2002. Influence of ingredient particle size and dietary inclusion level of pre-gelatinised maize starch on apparent nutrient digestibility of diets for South African abalone ( $\mathrm{Ha}$ liotis midae L.). Aquaculture 212, 299-309

Santos dos G.T., Petit H.V., 1996. Prediction of total fecal output in sheep fed silage using the Captec chrome controlled-release capsule. Small Ruminant Res. 20, 223-227

Schang M.J., Sibbald I.R., Hamilton R.M.G., 1983. Comparison of two direct bioassays using young chicks and two internal indicators for estimating the metabolizable energy content of feedingstuffs. Poultry Sci. 62, 117-124

Schiere J.B., Ibrahim M.N.M., Sewalt V.J.H., Zemmelink G., 1989. Response of growing cattle given rice straw to lickblocks containing urea and molasses. Anim. Feed Sci. Tech. 26, 179-189

Scott T.A., Baldaji F., 1997. Comparison of inert markers [chromic oxide or insoluble ash (Celite $\left.{ }^{\mathrm{TM}}\right)$ ] for determining apparent metabolizable energy of wheat-or barley-based broiler diets with or without enzymes. Poultry Sci. 76, 594-598

Scott T.A., Silversides F.G., Classen H.L., Swift M.L., Bedford M.R., Hall J.W., 1998. A broiler chick bioassay for measuring the feeding value of wheat and barley in complete diets. Poultry Sci. 77, 449-455

Shabat T.M., 1993. Digestibility determination in Nile catfish fingerlings using internal and external markers. Vet. Med. J. Giza 41, 83-91

Sharma H.R., Ingalls J.R., McKirdy J.A., 1983. Feeding value of alkali-treated whole rye (Secale cereale L.) grain for lactating cows and its digestibility for sheep. Anim. Feed Sci. Tech. 10, 77-82

Shrivastava V.S., Talapatra S.K., 1962. Pasture studies in Uttar Pradesh. II. Use of some natural indicators to determine the plane of nutrition of a grazing animal. Indian J. Dairy Sci. 15, 154-160

Sintayehu A., Mathies E., Meyer-Burgdorf K.H., Rosenow H., Günther K.D., 1996. Apparent digestibilities and growth experiments with tilapia (Oreochromis nilocitus) fed soybean meal, cottonseed meal and sunflower seed meal. J. Appl. Ichthyol. 12, 125-130

Sriwattanasombat P., Wanapat M., 1983. Supplementation of urea-treated straw with dried leucaena (Leucaena leucocephalia) and water hyacinth (Eichhornia crassipes) leaf meals. Annual Report, The National Buffalo Research and Development Center Project, Department of Livestock Development, Bangkok (Thailand), pp. 170-179

Staples C.R., Fernando R.L., Fahey G.C. Jr., Berger L.L., Jaster E.H., 1984. Effects of intake of a mixed diet by dairy steers on digestion events. J. Dairy Sci. 67, 995-1006

Sunvold G.D., Cochran R.C., 1991. Technical note: evaluation of acid detergent lignin, alkaline peroxide lignin, acid insoluble ash, and indigestible acid detergent fiber as internal markers for prediction of alfalfa, bromegrass, and prairie hay digestibility by beef steers. J. Anim. Sci. 69, 4951-4955

Sutton E.I., Bowland J.P., McCarthy J. F., 1977. Studies with horses comparing 4N-HCl insoluble ash as an index material with total fecal collection in the determination of apparent digestibilities. Can. J. Anim. Sci. 57, 543-549

Tacon A.G.J., Rodrigues A.M.P., 1984. Comparison of chromic oxide, crude fibre, polyethylene and acid-insoluble ash as dietary markers for the estimation of apparent digestibility coefficients in rainbow trout. Aquaculture 43, 391-399 
Thonney M.L., 1981. Acid insoluble ash as a digestion marker. Proceedings of the Cornell Nutrition Conference, Cornell University, Ithaca, NY (USA), pp.118-122

Thonney M.L., Duhaime D.J., Moe P.W., Reid J.T., 1979. Acid insoluble ash and permanganate lignin as indicators to determine digestibility of cattle rations. J. Anim. Sci. 49, 1112-1116

Thonney M.L., Palhof B.A., DeCarlo M.R., Ross D.A., Firth N.L., Quaas R.L., Perosio D.J., Duhaime D.J., Rolins S.R., Nour A.Y.M., 1985. Sources of variation of dry matter digestibility measured by the acid insoluble ash marker. J. Dairy Sci. 68, 661-668

Tillman P.B., Waldroup P.W., 1988a. Assessment of extruded grain amaranth as a feed ingredient for broilers. 1. Apparent metabolizable energy values. Poultry Sci. 67, 641-646

Tillman P.B., Waldroup P.W., 1988b. Assessment of extruded grain amaranth as a feed ingredient for broilers. 2. Apparent amino acid availability values. Poultry Sci. 67, 647-651

Trouten-Radford L.M., Valdes E.V., Dufresne A.L., Mcbride B.W., 1995. Total fecal collection and acid-insoluble ash as measures of dry matter digestibility by Kowari (Dasyuriodes brynei). Proceedings of the 1ste Annual Conference of the Nutrition Advisory Group of the American Zoo and Aquarium Association, Toronto (Canada), pp. 218-222

Trung L.T., Palo L.P., Atega T.A., Bien R.R., Lapinid R.R., 1987. Dose responses of goats fed ureatreated rice straw with varying supplementation rates: intake and digestibility by markers. $\mathrm{Ru}-$ minant feeding systems utilizing fibrous agricultural residues - 1987, International Development Program of Australian Universities and Colleges Ltd., Canberra (Australia), pp. 245-251

Udén P., 1984. Digestibility and digesta retention in dairy cows receiving hay or silage at varying concentrate levels. Anim. Feed Sci. Tech. 11, 279-291

Undersander D.J., Cole N.A., Naylor C.H., 1987. Digestibility by lambs of water-stressed alfalfa as determined by total collection or internal markers. J. Dairy Sci. 70, 1719-1723

Vandenberg G.W., Noüe de la J., 2001. Apparent digestibility comparison in rainbow trout (Oncorhynchus mykiss) assessed using three methods of faeces collection and three digestibility markers. Aquacult. Nutr. 7, 237-245

Van Keulen J., Young B.A., 1977. Evaluation of acid-insoluble ash as a natural marker in ruminant digestibility studies. J. Anim. Sci. 44, 282-287

Varel V.H., Jung H.G., Pond W.G., 1988. Effects of dietary fiber on young adult genetically lean, obese and contemporary pigs: rate of passage, digestibility and microbiological data. J. Anim. Sci. 66, 707-712

Vogtmann H., Pfirter H.P., Prabucki A.L., 1975. A new method of determining metabolizability of energy and digestibility of fatty acids in broiler diets. Brit. Poultry Sci. 16, 531-534

Vohra P., 1972. Evaluation of metabolizable energy for poultry. World Poultry Sci. J. 28, 204-214

Wetherbee B.M., Gruber S.H., 1993. Use of acid-insoluble ash as a marker in absorption efficiency studies with the lemon shark. Prog. Fish-Cult. 55, 270-274

Wiesemuller W., Poppe S., Breite L., Meier H., 1981. Digestibility of amino acids in lucerne silages (in German). Tierernähr. Futt. 12, 277-288

Wilson R.K., Winter K.A., 1984. An evaluation of acid-insoluble ash as a predictor of feed digestibility in ruminants. Irish J. Agr. Res. 23, 97-98

Wünsche J., Borgmann E., Hennig U., Kreienbring F., Bock H.D., 1984. Use of ash insoluble in HCl as indicator for estimating digestibility of nutrients including amino acids at the end of the small intestine and of the whole digestive tract in pigs (in German). Arch. Anim. Nutr. 34, 817-831

Yen J.T., Tess M.W., Pond W.G., Dickerson G.E., 1983. Digestibility and metabolism of dietary nitrogen and energy in contemporary, genetically lean and obese pigs as estimated by total fecal collection and acid insoluble ash. J. Anim. Sci. 56, 426-430 
Yin Y.-L., McEvoy J.D., Schulze H., McCracken K.J., 2001. Effects of xylanase and antibiotic addition on ileal and faecal apparent digestibilities of dietary nutrients and evaluating HCl-insoluble ash as a dietary marker in growing pigs. Anim. Sci. 72, 95-103

Zeoula L.M., Borges I., Branco A.F., Prado I.N., Moreira H.L.M., Salina J.L., Moraes de G.V., 1994. Evaluation of markers in digestibility studies in ruminants (in Portuguese). Rev. Unimar 16, 165-174

\section{STRESZCZENIE}

Popiół nierozpuszczalny w kwasie jako wskaźnik w doświadezeniach nad oznaczaniem strawności skladników pokarmowych: przegląd

Zastosowanie wskaźników do oznaczania strawności składników pokarmowych pasz pozwala na uniknięcie konieczności oznaczania ilości pobranej paszy i wydalonego kału. Choć w ciągu wielu lat badano wiele wewnętrznych i zewnętrznych wskaźników, to nie został jeszcze znaleziony taki, który spełniałby kryteria idealnego wskaźnika. W prezentowanym przeglądzie omówiono użycie popiołu nierozpuszczalnego w kwasie (AIA) jako wskaźnika w badaniach strawnościowych. Do oznaczania zawartości AIA stosowane są zwykle trzy warianty oryginalnej grawimetrycznej metody, opartej na spopieleniu badanych prób, gotowaniu w roztworze kwasu chlorowodorowego i powtórnym spopieleniu.

W podsumowaniu otrzymanych wyników w doświadczeniach przeprowadzonych na wielu gatunkach zwierząt żywionych różnymi paszami można uznać, że w kale znajduje się około 100\% AIA podanego w dawce pokarmowej. W 44 doświadczeniach strawnościowych, w których porównano metodę wskaźnikową, z użyciem AIA, z wynikami metody klasycznej, wykonanych na różnych gatunkach zwierząt, w 26 otrzymano podobne wyniki, w 9 - były niższe, a w 10 wyższe. Nie stwierdzono istotnej dziennej zmienności w ilości AIA w kale drobiu, owiec, świń i bydła. Najpowszechniejszą przyczyną niepowodzenia przy zastosowaniu AIA jako wskaźnika są błędy analityczne, szczególnie w przypadku pasz o małej zawartości AIA.

W podsumowaniu można stwierdzić, że AIA jest dobrym wskaźnikiem, z wieloma zaletami, który może być z powodzeniem stosowany do oznaczania strawności składników pokarmowych w określonych warunkach i z zachowaniem pewnej ostrożności. 